\title{
Study on aerated concrete using steam curing test method
}

\author{
Rohith Naidu T Y*, G.V.V Satyanarayana ${ }^{1}$ \\ * PG student, Civil Engineering Department, GRIET, Hyderabad, India. \\ ${ }^{1}$ Professor, Civil Engineering Department, GRIET, Hyderabad, India.
}

\begin{abstract}
The Accumulation of warm and moisture in building walls plays an vital role in its upkeep and power conservation. Aerated Concrete block, an environmental material gives an anticipated result to building construction. Aerated Concrete can build light weight, eco-friendly, non-structural wall, reduced dead weight concrete blocks. Aerated Concrete is developed introducing aluminium powder which reacts with the calcium hydroxide on hydration of cement. Several curing test methods are done to find out the optimum dosage of aluminium content. The Aerated concrete blocks are pre-casted by mixing Portland cement, fly ash, GGBS, quarry dust, lime stone powder, water and aluminium powder.
\end{abstract}

Keywords: Aerated Concrete, Light weight, curing, Aluminium powder.

\section{Introduction}

Aerated concrete production involves the addition of a foaming agent like $\mathrm{Al}$ powder to a mix of cement, the combination of fine aggregates and water which reacts with the lime in cement manufactures a lightweight porous material. Aerated Concrete blocks are also one of the result for brick substitute. Aerated Concrete is one of all the environmental products.

Several curing tests of Aerated Concrete were studied in this work. Several instrumented experiments were performed to characterize aerated concrete blocks. These studies include the variant of compressive strength within a typical block.

Steam curing of concrete at air pressure has the advantage of fasting the hydration reactions of portland cement. Consequently, the material develops compressive strength and reduces its porosity during a shorter time compared with standard curing under ambient conditions. under traditional ambient conditions, counting on the kind of cement and its fineness, the compressive strength will reach up to fifty $50 \%$ of the final strength in 3 days, and $80 \%$ in ten days. Accelerated curing will increase the strength gain at early ages, even though there's typically a strength reduction at later ages compared to straightforward curing.

\subsection{Objective}

To study the steam curing method of the aerated concrete of optimum dosage of aluminium powder. To investigate the influence of the steam curing method on the compressive strength of aerated concrete. To carry out all the mixed proportions for the compression test. To execute the volumetric analysis of the aerated concrete.

\section{Literature Survey}

Jagadish vengala et al., (2019): terminated that the compressive strength of autoclaved aerated concrete blocks was drastically reduced after they are under an autoclave machine of bound pressure and temperature of 1500 degrees Celcius and suddenly they're cooled by immersing in water. Results show thirty-five \% reduction in strength of autoclave aerated concrete blocks.[1]

Rana Shabbar et al. (2017) created aerated concrete by introducing gas into concrete, the quantity depends upon the necessities for strength. The aim of this study was to analyse the influence of the powder content on the mechanical properties of aerated concrete namely; compressive and flexural strengths, modulus of physical property, density, and body. The results indicated that a rise in metal content caused a decrease within the compressive 
and tensile strengths. It additionally created a decrease within the modulus of physical property. Once the metal content enlarged, the density diminished and therefore the body enlarged.[4]

\section{Methodology}

3.2 Mix Proportions

A) Mix Proportion 1

\begin{tabular}{|c|c|}
\hline Material & $\begin{array}{c}\text { Quantity of Materials } \\
\text { per Block (Grams) }\end{array}$ \\
\hline Cement & 200 \\
\hline Sand & 400 \\
\hline Water & 100 \\
\hline Aluminium Powder & $0.1 \%, 0.15 \%, 0.2 \%$ \\
\hline Super Plasticizer & $1 \%$ \\
\hline
\end{tabular}

Concrete is mixed for $0.1 \%, 0.15 \%$ and $0.2 \%$ of aluminum powder and density is found to be from 800-1200 for different types of trails which comes under a lightweight concrete but not an accurate aerated concrete.

The concrete is again mixed with PCE superplasticizer (polycarboxylate ether) to decrease water content and to increase the workability of the concrete. Since the density of aerated concrete is more, the sand is totally replaced with lime-stone powder and quarry dust and again a separate mixproportion was designed.

B) Mix Proportion 2

\begin{tabular}{|c|c|}
\hline Material & $\begin{array}{c}\text { Quantity of Materials } \\
\text { per Block (Grams) }\end{array}$ \\
\hline Cement & 600 \\
\hline Quarry Dust & 150 \\
\hline Limestone Powder & 150 \\
\hline Water & 375 \\
\hline Aluminium Powder & $0.1 \%, 0.15 \%, 0.2 \%$ \\
\hline
\end{tabular}

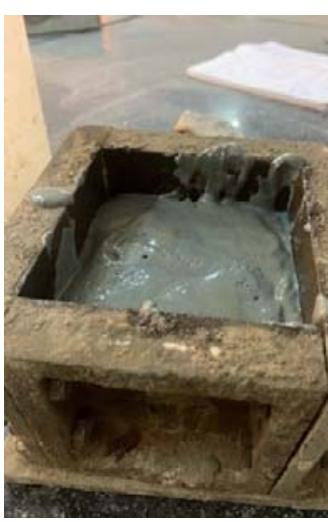

Fig 1. Concrete After pouring into the mold

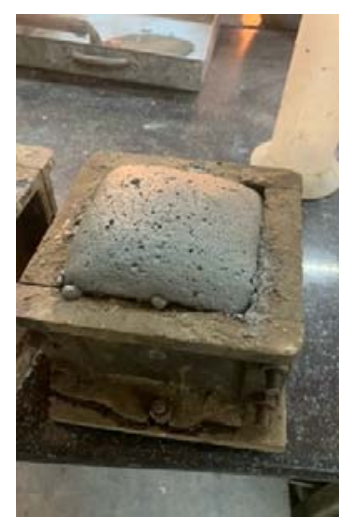

Fig 2. Concrete After 30 minutes after pouring into the mold
As the density and compression strength using limestone powder and quarry dust was found to be less, one more proportion was designed by adding fly ash, and GGBS.

C) Mix Proportion 3

\begin{tabular}{|c|c|}
\hline Material & $\begin{array}{c}\text { Quantity of Materials } \\
\text { per Block (Grams) }\end{array}$ \\
\hline Cement & 250 \\
\hline Fly Ash & 250 \\
\hline Quarry Dust & 80 \\
\hline Limestone Powder & 80 \\
\hline GGBS & 80 \\
\hline Water & 333 \\
\hline Aluminium Powder & $0.1 \%, 0.15 \%, 0.2 \%$ \\
\hline
\end{tabular}

The density of the concrete replacing lime-stone powder and quarry dust for aerated concrete is found to be from 600-1000 for different trails.

The several samples of different aluminum content were taken to conduct compressive test using steam curing method.

\subsection{Steam Curing Method}

Steam curing is curing in vapor at atmospherically or higher pressures. once cured at atmospheric pressure, the enclosure temperatures are typically between 100 to $105^{\circ} \mathrm{C}$. Steam curing is used wherever early strength gain is needed and wherever heat is required for hydration, like in cold weather. The entire mold was placed into the steam curing tank as per the procedure.

The Fig 3. below shows the sample were taken and conducted steam curing for 3 hours at $100^{\circ} \mathrm{c}$.

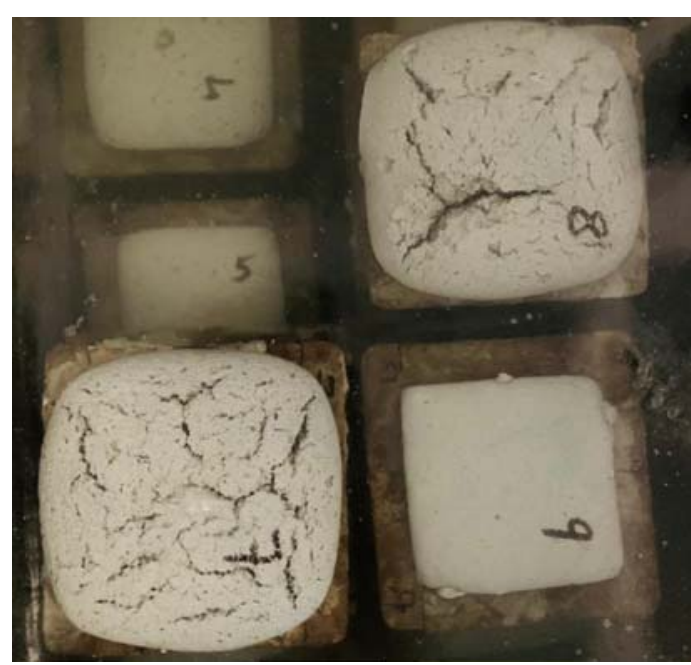

Fig 3. Concrete Molds Placed in Steam Curing Tank. 
After the curing period the samples were kept in the room temperature to cooldown the molds.

Once the Samples are cooldown, the samples were unmolded and kept in the oven for 3 hours at $100 \pm 5^{\circ} \mathrm{c}$ to reduce the water content in the concrete block.

After the water content is reduced in the concrete block, the concrete blocks are kept aside for 15 minutes to cooldown.

Fig 4. Shows the above part of the concrete is cut using hacksaw blade to form a uniform shape of $100 \mathrm{mmx} 100 \mathrm{~mm} \times 100 \mathrm{~mm}$.

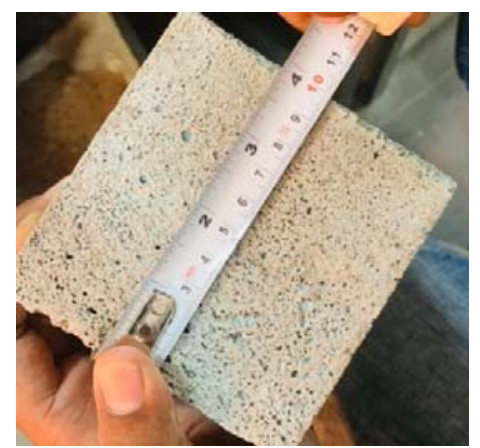

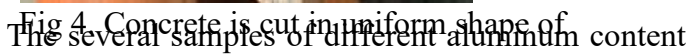

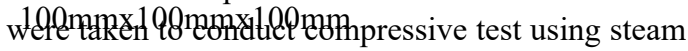
curing method.

\section{Results}

4.1.1 Density of Aerated Blocks for $0.1 \%$ of Aluminium content

\begin{tabular}{|c|c|c|c|c|}
\hline \multirow{2}{*}{$\begin{array}{c}\text { S1. } \\
\text { No }\end{array}$} & \multirow{2}{*}{$\begin{array}{c}\text { Type of } \\
\text { Block }\end{array}$} & \multicolumn{3}{|c|}{ Density of the Blocks } \\
\cline { 3 - 5 } & & Block 1 & Block 2 & Block 3 \\
\hline 1 & Proportion 1 & 1022 & 964 & 1152 \\
\hline 2 & Proportion 2 & 1010 & 1004 & 805 \\
\hline 3 & Proportion 3 & 907 & 836 & 988 \\
\hline
\end{tabular}

4.1.2 Change in volume of Aerated concrete for $0.1 \%$ of Aluminium Content

\begin{tabular}{|c|c|c|c|c|}
\hline \multirow{3}{*}{ S1. } & \multirow{3}{*}{ Nype of } & \multicolumn{3}{|c|}{ Change in volume of the } \\
Block & \multicolumn{3}{|c|}{ Blocks } \\
\cline { 3 - 5 } & & Block 1 & Block 2 & Block 3 \\
& & & & \\
\hline
\end{tabular}

\begin{tabular}{|c|c|c|c|c|}
\hline 1 & Proportion 1 & - & - & - \\
\hline 2 & Proportion 2 & $28 \%$ & $37 \%$ & $23 \%$ \\
\hline 3 & Proportion 3 & $56 \%$ & $48 \%$ & $40 \%$ \\
\hline
\end{tabular}

4.1.3 Compressive Strength of Aerated Concrete for $0.1 \%$ of Aluminium Content

\begin{tabular}{|c|c|c|c|c|}
\hline \multirow{2}{*}{ S1. } & \multirow{2}{*}{ No } & Type of & \multicolumn{3}{|c|}{ Strength of the Blocks } \\
Block & & \multicolumn{3}{|c|}{$\mathrm{mm} \mathrm{m}^{2}$} \\
\cline { 3 - 5 } & & Block 1 & Block 2 & Block 3 \\
\hline 1 & Proportion 1 & - & - & - \\
\hline 2 & Proportion 2 & 3.5 & 2.6 & 3.1 \\
\hline 3 & Proportion 3 & 2.6 & 2.8 & 3.4 \\
\hline
\end{tabular}

4.2.1 Density of Aerated Blocks for $0.15 \%$ of Aluminium content

\begin{tabular}{|c|c|c|c|c|}
\hline S1. & Type of & \multicolumn{3}{|c|}{ Density of the Blocks } \\
No & Block & Block 1 & Block 2 & Block 3 \\
\cline { 3 - 5 } & & 997 & 1074 & 1241 \\
\hline 1 & Proportion 1 & & & \\
\hline 2 & Proportion 2 & 740 & 763 & 695 \\
\hline 3 & Proportion 3 & 737 & 855 & 942 \\
\hline
\end{tabular}

4.2.2 Change in volume of Aerated concrete for $0.15 \%$ of Aluminium Content

\begin{tabular}{|c|c|c|c|c|}
\hline \multirow[t]{2}{*}{$\begin{array}{l}\text { Sl. } \\
\text { No }\end{array}$} & \multirow[t]{2}{*}{$\begin{array}{l}\text { Type of } \\
\text { Block }\end{array}$} & \multicolumn{3}{|c|}{$\begin{array}{c}\text { Change in volume of the } \\
\text { Blocks } \%\end{array}$} \\
\hline & & Block 1 & Block 2 & Block 3 \\
\hline 1 & Proportion 1 & - & - & - \\
\hline 2 & Proportion 2 & $37 \%$ & $44 \%$ & $48 \%$ \\
\hline 3 & Proportion 3 & $62 \%$ & $55 \%$ & $43 \%$ \\
\hline
\end{tabular}

4.2.3 Compressive Strength of Aerated Concrete for $0.15 \%$ of Aluminium Content 


\begin{tabular}{|c|c|c|c|c|}
\hline \multirow{2}{*}{$\begin{array}{c}\text { S1. } \\
\text { No }\end{array}$} & Type of & \multicolumn{3}{|c|}{ Strength of the Blocks } \\
& & \multicolumn{3}{|c|}{$\mathrm{N} / \mathrm{mm}^{2}$} \\
\cline { 3 - 5 } & & Block 1 & Block 2 & Block 3 \\
\hline 1 & Proportion 1 & - & - & - \\
\hline 2 & Proportion 2 & 3.0 & 2.9 & 2.8 \\
\hline 3 & Proportion 3 & 2.0 & 2.2 & 3.2 \\
\hline
\end{tabular}

4.3.1 Density of Aerated Blocks for $0.2 \%$ of Aluminium content

\begin{tabular}{|c|c|c|c|c|}
\hline \multirow{2}{*}{$\begin{array}{c}\text { S1. } \\
\text { No }\end{array}$} & \multirow{2}{*}{$\begin{array}{c}\text { Type of } \\
\text { Block }\end{array}$} & \multicolumn{3}{|c|}{ Density of the Blocks } \\
\cline { 3 - 5 } & & Block 1 & Block 2 & Block 3 \\
\hline 1 & Proportion 1 & 947 & 801 & 895 \\
\hline 2 & Proportion 2 & 912 & 973 & 696 \\
\hline 3 & Proportion 3 & 572 & 525 & 687 \\
\hline
\end{tabular}

4.3.2 Change in volume of Aerated concrete for $0.2 \%$ of Aluminium Content

\begin{tabular}{|c|c|c|c|c|}
\hline \multirow{2}{*}{$\begin{array}{c}\text { S1. } \\
\text { No }\end{array}$} & Type of & \multicolumn{3}{|c|}{$\begin{array}{c}\text { Change in volume of the } \\
\text { Block }\end{array}$} \\
\cline { 3 - 5 } & & \multicolumn{3}{|c|}{ Blocks \% } \\
\cline { 3 - 5 } & & Block 1 & Block 2 & Block 3 \\
\hline 1 & Proportion 1 & - & - & - \\
\hline 2 & Proportion 2 & $47 \%$ & $53 \%$ & $55 \%$ \\
\hline 3 & Proportion 3 & $100 \%$ & $80 \%$ & $65 \%$ \\
\hline
\end{tabular}

4.3.1 Compressive Strength of Aerated Concrete for $0.2 \%$ of Aluminium Content

\begin{tabular}{|c|c|c|c|c|}
\hline \multirow{2}{*}{$\begin{array}{c}\text { Sl. } \\
\text { No }\end{array}$} & Type of & \multicolumn{3}{|c|}{ Strength of the Blocks } \\
& & \multicolumn{3}{|c|}{$\mathrm{N} / \mathrm{mm}^{2}$} \\
\cline { 3 - 5 } & & Block 1 & Block 2 & Block 3 \\
\hline 1 & Proportion 1 & - & - & - \\
\hline 2 & Proportion 2 & 2.5 & 2.4 & 2.2 \\
\hline 3 & Proportion 3 & 1.6 & 1.8 & 1.7 \\
\hline
\end{tabular}

Graph Shows the Comparition of Compressive strength and Al Powder for Proportion 2

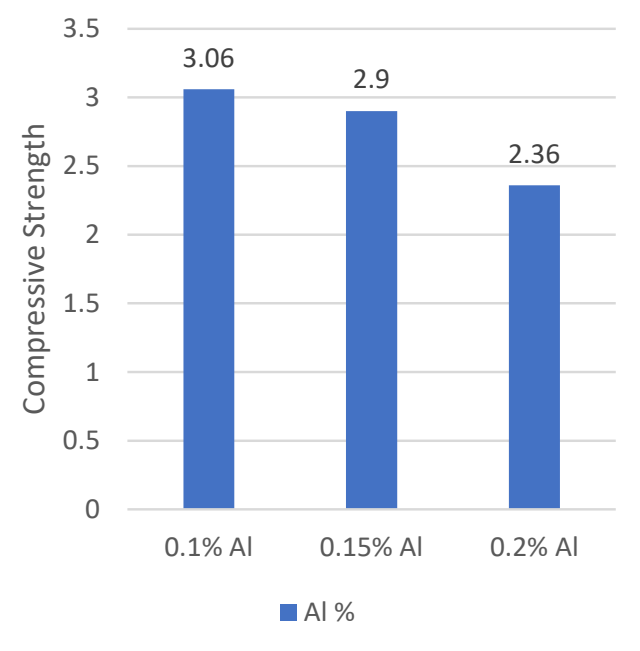

Fig 5. Compressive Strength vs Aluminum Powder.

Graph Shows the Comparition of Compressive strength and Al Powder for Proportion 3

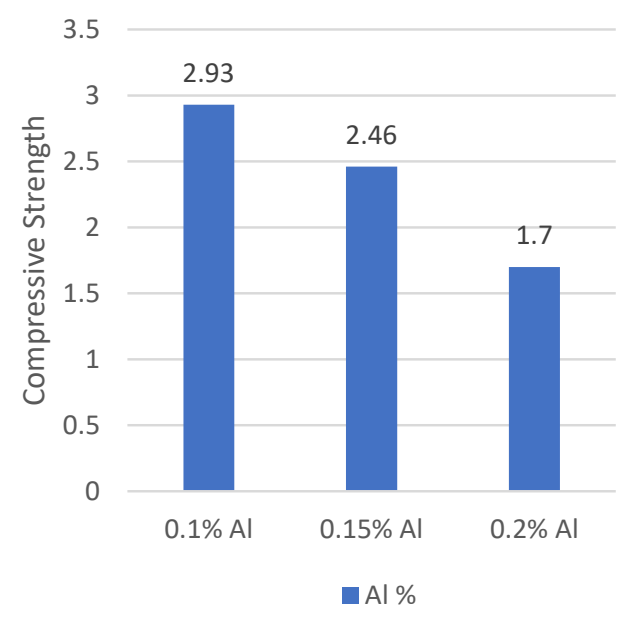

Fig 6. Compressive Strength vs Aluminum Powder. 
Graph Shows the Comparition of Change in volume and Al Powder for Proportion 2

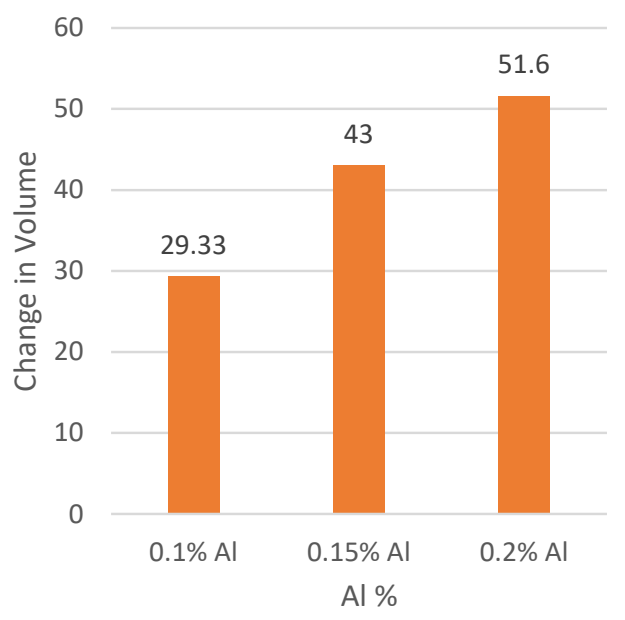

Fig 7. Change in volume vs Aluminum Powder.

Graph Shows the Comparition of Change in volume and Al Powder for Proportion 3

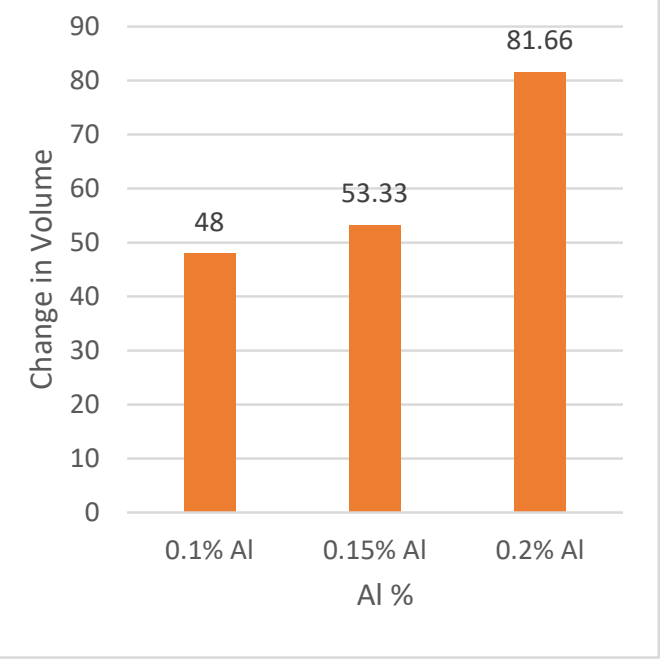

Fig 8. Change in volume vs Aluminum Powder.

\section{Conclusion}

- As we can see the above Fig 5 and Fig 6 we can clearly conclude that, if we increase the aluminium content there is decrease in the compressive strength.

- By using the steam curing method, the compressive strength was found to be very low.

- We conclude that by seeing the fig 7 and fig 8 if there is increase in aluminium powder there is also increase in the volume of the concrete.

- By using the steam curing method for aerated concrete, we cannot use the concrete as a replacement of bricks.

\section{Reference}

1. Jagadish vengala, Shivakumar mangloor, talla krishna, Chaitanya goud." Performance of autoclave aerated concrete blocks under varying temperatures" international journal of recent technology and engineering (IJRE) ISSN: 22793878, volume-7.

2. Manikandan, Dr S. Gopalakrishnan, A detail study on autoclave aerated concrete, Int. Res. J. Eng. Technol. (IRJET), e-ISSN: 2395-0056 Volume: 05 (2018) p-ISSN: 2395-0072.

3. Muthu Krishnan, K. Muthu Kumar, R. Sibi Rajan, Effect of temperature variation on autoclave aeratedconcrete beam using ceramic waste as coarse aggregate, Int. J. Curr. Eng. Scientific Res. 4 (2394069712) (2017).

4. Rana Shabbar, Paul Nedwell, Zhangjian, Mechanical properties of lightweight aerated concrete with different aluminium powder content (2017), ASCMCES-17

5. M. Gunasekaran, G. Saranya, L. Elamaran, P. Sakthivel, Development of light weight concrete by using autoclaved aerated concrete (2016), ISSN 2349-6010.

6. Mallampalli. Ch. G. Subash, V.S.V. Satyannarayana, Janga Srinivas, autoclaved aerated concrete (AAC) blocks: a revolution building material in construction production, Int. J. Sci. Technol. Manage. 5 (2016).

7. Ali J. Hamad, Materials, production, properties and application of aerated lightweight concrete: review, J. Mater. Sci. Eng. 2 (2014). 